\title{
RESULTS OF COMPREHENSIVE STUDIES OF THE UNDERGROUND HYDROSPHERE WITHIN THE WESTERN SHOULDER OF THE BAIKAL RIFT (AS EXEMPLIFIED BY THE BAYANDAI - KRESTOVSKY CAPE SITE)
}

\author{
K. Zh. Seminsky ${ }^{1}$, M. A. Tugarina ${ }^{2}$ \\ ${ }^{1}$ Institute of the Earth's Crust, Siberian Branch of RAS, 664033, Irkutsk, Lermontov street, 128, Russia \\ ${ }^{2}$ Irkutsk State Technical University (National Research University), 664074, Irkutsk, Lermontov street, 83, \\ Russia
}

\begin{abstract}
The subject of comprehensive studies is the underground hydrosphere of the upper crust of the western shoulder of the Baikal rift, being characterized by high tectonic activity in the recent stage of tectogenesis. The studies were focused on the Bayandai - Krestovsky Cape site, considering it as a benchmark for the territory of the Western Pribiakalie (Fig. 1). The available hydrogeological survey database is used to study underground waters circulating at depth of several kilometers. Analyses of deeper waters are conducted on the basis of geophysical data.

According to results of initial geological and geophysical studies [Семинский и др., 2010], the crust at the junction of the Siberian crater and the Sayan-Baikal folded belt is characterized by a hierarchic zone-block structure (Fig. 2). Regardless of the scale of studies, the territory under study can be divided into sections of two types, that alternate from NW to SE and represent wide highly destructed zones and relatively monolithic blocks of the crust. The Obruchev fault system is distinguished as the main inter-block zone (the $2^{\text {nd }}$ hierarchic level in the study area). It represents the $50 \mathrm{~km}$ long NW shoulder of the Baikal rift (the $1^{\text {st }}$ hierarchic level) and includes the Morskaya, Primorskaya and Prikhrebtovaya inter-plate zones (the $3^{\text {rd }}$ hierarchic level). These zones are traced from depth of dozens of kilometers; at the surface, they are represented by fault structures of the highest hierarchic levels.
\end{abstract}

Specific features of the current zone-block divisibility of the crust serve as the structural basis for interpreting the materials obtained by hydrogeological studies conducted on the Bayandai - Krestovsky Cape site to research the distribution, mineralization and macro-component compositions of waters which represent the subsurface part of the underground lithosphere in the study area. The research is based on analyses of the underground water samples from 46 observation points scattered within the study area. The available amount of sample data can actually be considered as a complete base of standard hydrogeological data for the study area.

The known specific features of hydrogeology of the Western Pribaikalie are confirmed by the general analysis of the available data. In general, fresh waters of subsurface origin of the mid- and submontane regions are dominant. In the anionic composition of the waters, hydrocarbon ion is predominant. Calcium and magnesium are abundant among basis ions, while potassium and sodium are rare. With the detail data on the Bayandai - Krestovsky Cape site, the above conclusions are more precisely determined, and it is generally concluded that the structural tectonic factor controls the hydrogeology of the region.

The analysis of mineralization, composition, temperature and other characteristics of the underground waters (Fig. 3-6) show that at the low hierarchic level the NW boundary of the Obruchev inter-block zone performs a function of a distinct hydrogeological barrier which represents the marginal suture of the Siberian platform. The marginal suture is active at the currently stage of tectogenesis. It separates low-mineralized and fresh waters of the platform block from fresh and ultrafresh waters of the mountainous area. The Predbaikalskaya, Prikhrebtovaya, Primorskaya and Morskaya inter-plate zones are distinguished within the limits of these structures. At the given hierarchic level, they control the positions of the corresponding anomalies in terms of water exchange modes, general mineralization and water cut ratios. The magneto-telluric sounding data (Fig. 2 and 7) suggest that the anomalies are subsurface manifestations of deep sections of conductivity; such sections have fluid origin in the region under study. Specific features of the structure of such anomalies are controlled by the presence of inter-block zones of the fault level of the hierarchy. The inter-block zones are composed of tectonic dislocations of various ranks. Depending on their specific internal structures, such dislocations can act as impermeable screens or channels for migration of fluids.

Based on the joint interpretation of the results of the hydrogeological studies and the earlier geological and geophysical studies on the Bayandai - Krestovsky Cape site, a conceptual model showing specific features of fluid saturation of the upper crust of the western shoulder of the Baikal rift is developed (Fig. 8). Generally speaking, the underground hydrosphere of the Western Pribaikalie is a uniform system at the subsurface and deeper levels, and its structure and content are mainly determined by the active zone-block structure of the crust in the region under study. Its nature is controlled by the development of the Baikal rift, which western shoulder (and also the adjacent platform region) is occupied by a hierarchy of subvertical zones in the upper crust that are anomalous in terms of permeability concerning underground waters. In the tectonically active seg- 
ment of the region, these zones are larger than the blocks and thus cause more significant dislocations and higher water-cut of the crust. The relationship between dislocations and water-cut allows determining specific features of the zone-block structure by regions by applying methods of hydrogeological surveys for studies of shallow horizons and geophysical methods, which are more sensitive to fluid contents, for studies of deeper layers. On the other side, geophysical and hydrogeological data (at least on tectonically active regions) should be interpreted with account to the concept that the fields under study depend on the structural status of the rock massif, rather than on the lithology.

Key words: underground hydrosphere, inter-block zone, fault, underground water, mineralization, macro-component composition, magneto-telluric sounding (MTS), Baikal rift.

Recommended by S.I. Sherman 11 May 2011

Citation: Seminsky K.Zh., Tugarina M.A. Results of comprehensive studies of the underground hydrosphere within the western shoulder of the Baikal rift (as exemplified by the Bayandai - Krestovsky Cape site)// Geodynamics \& Tectonophysics. 2011. V. 2. № 2. P. 126-144.

\title{
РЕЗУЛЬТАТЫ КОМПЛЕКСНЫХ ИССЛЕДОВАНИЙ ПОДЗЕМНОЙ ГИДРОСФЕРЫ ЗАПАДНОГО ПЛЕЧА БАЙКАЛЬСКОГО РИФТА (НА ПРИМЕРЕ УЧАСТКА П. БАЯНДАЙ - М. КРЕСТОВСКИЙ)
}

\author{
К. Ж. Семинский ${ }^{1}$, М. А. Тугарина ${ }^{2}$ \\ ${ }^{1}$ Институт земной коры СО РАН, 664033, Иркутск, ул. Лермонтова, 128, Россия \\ ${ }^{2}$ Национальный исследовательский Иркутский государственный технический университет, 664074, \\ Иркутск, ул. Лермонтова, 83, Россия
}

\begin{abstract}
Аннотация: Комплексные исследования подземной гидросферы проведены для верхней части земной коры западного плеча Байкальского рифта, который характеризуется высокой тектонической активностью на современном этапе тектогенеза. Работы осуществлялись в пределах участка пос. Баяндай - мыс Крестовский, который в плане тектонических особенностей может рассматриваться в качестве эталонного для территории Западного Прибайкалья в целом (рис. 1). Изучение вод до глубин в первые километры базировалось на гидрогеологических данных, тогда как более глубокие уровни подземной гидросферы анализировались на основе геофизических материалов.

Согласно результатам предварительных геолого-геофизических работ на участке исследований [Семинский и дp., 2010], установлено иерархическое зонно-блоковое строение земной коры области сочленения Сибирского кратона и Саяно-Байкальского складчатого пояса (рис. 2). Независимо от масштаба исследований изученная территория делится на два типа участков, которые, чередуясь в направлении с северо-запада на юго-восток, представляют широкие интенсивно нарушенные зоны и сравнительно монолитные блоки земной коры. В качестве главной межблоковой зоны изученного региона выделяется Обручевская разломная система (2-й иерархический уровень), которая представляет северо-западное плечо Байкальского рифта (1-й иерархический уровень) и имеет ширину $\approx 50$ км. Она состоит из Морской, Приморской и Прихребтовой межблоковых зон (3-й иерархический уровень), трассирующихся из глубин в десятки километров и выраженных у поверхности разломными структурами высших уровней иерархии.

Особенности современной зонно-блоковой делимости земной коры послужили структурной основой для интерпретации материалов гидрогеологических работ на участке пос. Баяндай - мыс Крестовский, заключающихся в изучении распределения, минерализации и макрокомпонентного состава вод, образующих близповерхностную часть подземной гидросферы изучаемого региона. Исследования проведены на базе результатов опробования подземных вод в 46 точках изучаемой полосы, образующих для этой территории практически полный банк стандартных гидрогеологических данных.

В ходе общего анализа материалов опробования подтвердились известные особенности гидрогеологии Западного Прибайкалья. В целом здесь доминируют пресные воды средне- и предгорных районов поверхностного происхождения, в анионном составе которых преобладает гидрокарбонат-ион, а среди катионов - кальций, магний и, реже, калий и натрий. Вместе с тем, материалы, полученные для участка детальных исследований пос. Баяндай - мыс Крестовский, дали возможность уточнить эти представления и сделать общий вывод об определяющей роли структурнотектонического фактора в гидрогеологии региона.

Анализ минерализации, состава, температуры и других особенностей подземных вод (рис. 3-6) показал, что на низком уровне иерархии в качестве отчетливого гидрогеологического рубежа выступает северо-западная граница Обручевской межблоковой зоны, которая отражает структуру краевого шва Сибирской платформы, активизированного на современном этапе тектогенеза. Эта граница отделяет слабоминерализованные и пресные воды платформенного блока от пресных и ультрапресных вод горной области. В пределах этих структурных подразделений выделяются Предбайкальская, Прихребтовая, Приморская и Морская межблоковые зоны, которые на данном уровне иерар-
\end{abstract}


хии контролируют положение соответствующих аномалий по режиму водообмена, общей минерализации и степени обводненности. Судя по результатам магнитотеллурических зондирований (рис. 2, 7), эти аномалии являются близповерхностным проявлением глубинных участков проводимости, имеющих в рассматриваемом регионе флюидную природу. Особенности строения этих аномалий определяются наличием межблоковых зон разломного уровня иерархии, которые, в свою очередь, состоят из разноранговых тектонических нарушений, являющихся в зависимости от специфики внутренней структуры непроницаемыми упорами или каналами для миграции флюидов.

В итоге совместной интерпретации результатов гидрогеологических работ на участке пос. Баяндай - мыс Крестовский и материалов проведенных ранее геолого-геофизических исследований выявлены и представлены в виде концептуальной модели характерные особенности флюидонасыщенности верхней коры западного плеча Байкальского рифта (рис. 8). Установлено, что подземная гидросфера Западного Прибайкалья на близповерхностном и более глубоких уровнях образует по большому счету единую систему, строение и состав которой во многом определяются активной зонно-блоковой структурой земной коры. Ее характер контролируется развитием Байкальского рифта, на западном плече которого, а также в смежном платформенном регионе сформировалась иерархия зон, занимающих в верхней коре субвертикальное положение и являющихся аномальными в отношении проницаемости для подземных вод. Зоны в тектонически активной части региона в целом превышают блоки по размерам, что является причиной общей высокой нарушенности и обводненности земной коры. Взаимосвязь этих двух свойств позволяет выявлять специфику зонно-блоковой структуры конкретных регионов, используя гидрогеологическую съемку для самых верхних горизонтов, а чувствительные к содержанию флюида геофизические методы - для более глубоких. В то же время интерпретация данных геофизики и гидрогеологии, по крайней мере в тектонически активных регионах, должна прежде всего исходить из обусловленности изучаемых полей не составом пород, а структурным состоянием горного массива.

Ключевые слова: подземная гидросфера, межблоковая зона, разломы, подземные воды, минерализация, макрокомпонентный состав, магнитотеллурическое зондирование, Байкальский рифт.

\section{1. ВВЕДЕНИЕ}

Актуальность исследований подземной гидросферы определяется существенной ролью воды во многих процессах, происходящих в земной коре, в том числе в настоящее время. Методы исследования современного состояния гидросферы в первом приближении делятся на поверхностные и глубинные, что определяется не только их разрешающей способностью, но и существенными различиями в происхождении и состоянии воды, присутствующей на разных уровнях вертикального разреза коры. Базовыми для изучения подземных вод до глубины в первые километры являются гидрогеологические методы, тогда как по мере продвижения в глубь коры бо́льшую значимость приобретают различные методы геофизики, причем детальность исследования подземной гидросферы по известным причинам уменьшается. В этой связи особую актуальность приобретают исследования, при которых на одном объекте реализуются обе группы методов. Это позволяет, с одной стороны, установить характерные особенности подземной гидросферы конкретного региона в широком диапазоне глубин, а с другой - определить информативность и возможности отдельных методов ее исследования.

Байкальский рифт, как центральная часть одноименной рифтовой зоны, является удобным объектом для проведения работ подобного типа, поскольку, вопервых, характеризуется высокой современной активностью, а во-вторых, достаточно полно изучен в плане общих вопросов тектоники и гидрогеологии. В связи с этим целью представленных в статье исследований было выявление характерных особенностей подземной гидросферы западного плеча Байкальского рифта на основе проведения гидрогеологических работ на участке п. Баяндай - м. Крестовский (рис. $1, A$ ) и целенаправленного сопоставления их результатов с полученными для того же объекта геолого-геофизическими данными [Семинский и др., 2010].

\section{2. ТЕКТОНИЧЕСКИЕ ОСОБЕННОСТИ РАЙОНА ИССЛЕДОВАНИЙ}

Работы проводились в области сочленения древнего Сибирского кратона и Саяно-Байкальского складчатого пояса. Ее кайнозойская активизация привела к возникновению Байкальского рифта, западное плечо которого было полностью охвачено исследованиями на участке п. Баяндай - м. Крестовский (рис. 1). Главные закономерности геологического строения рассматриваемой территории представлены на рис. $1, B$, а особенности морфотектоники - на трехмерной модели рельефа (рис. 1, Б), построенной в результате ГИСобработки космоснимков типа SRTM (разрешение - до 90 м). На северо-западной половине полосовидного участка исследований распространены разнотипные комплексы Сибирского кратона, которые относительно спокойно залегают на периферии территории и интенсивно дислоцированы в районе р. Бугульдейка (Прибайкальский краевой прогиб). В юго-восточной приольхонской части обнажаются полихронные мета- 
морфические комплексы краевых поднятий СаяноБайкальского складчатого пояса. Контакт двух крупных тектонических единиц Центрально-Азиатского региона происходит по системе разломов краевого платформенного шва (Приморский сегмент), который представлен широкой полосой бластомилонитов и разнотипных интрузивных проявлений, включая гранитоиды приморского комплекса [Замараев, 1967; Наумов, 1974; Соотношение..., 1979; Structural and tectonic correlation..., 2005].

Краевые структуры были неоднократно активизированы, причем в результате кайнозойского тектогенеза это привело к образованию достаточно сложного рельефа. Согласно предыдущим работам [Карта..., 1979; Уфимцев, 1992; Перевозников, 1999; Мац и др., 2001], структурами 1-го порядка здесь являются Предбайкальский прогиб и Байкальский свод, которые состоят из ряда более мелких морфоструктур, вытянутых в пределах Западного Прибайкалья в северо-восточном направлении (рис. 1, b). Так, на участке исследований п. Баяндай - м. Крестовский представлены: Предбайкальский прогиб, Прибайкальский краевой выступ (флексура), Онотское плоское поднятие, Прихребтовая депрессия, Приморское глыбовое поднятие, Бугульдейско-Чернорудская впадина и Приольхонская краевая ступень.

В связи с тем, что полосовидный участок исследований в достаточной степени представляет главные тектонические особенности обширного Прибайкальского региона, в его пределах был реализован комплекс геолого-геофизических работ, позволивший получить качественно новые данные о структуре западного плеча Байкальского рифта [Семинский и др., 2010]. В результате этих предшествующих работ на основе интерпретации данных структурно-геологической съемки, морфотектонического анализа рельефа, магниторазведки, электроразведки методами естественного поля (ЕП) и симметричного профилирования (СЭП), магнитотеллурических зондирований (МТЗ) и эманационной съемки уточнены принципиальные особенности строения области сочленения Сибирской платформы и Саяно-Байкальского складчатого пояса, выявлена реальная картина нарушенности земной коры и впервые установлено ее соответствие теоретическим представлениям о зонно-блоковой структуре литосферы [Семинский, 2001; Seminskii, 2008] (рис. 2). Так, изученная территория делится на два типа участков, которые, чередуясь, представляют широкие подвижные зоны и сравнительно стабильные блоки земной коры. Зоны взаимодействия блоков отличаются повышенной плотностью разрывов, понижениями в рельефе, сложными по форме, но в целом положительными газовыми аномалиями, минимумами потенциала ЕП и контрастными минимумами удельного электрического сопротивления как у поверхности (данные СЭП), так и на глубине (данные МТЗ). Взаимное положение и соотношения размеров межблоковых зон, выявленных в ходе целенаправленного анализа геолого-геофизических данных, свидетельствуют об их иерархической соподчиненности.

В качестве элементов зонно-блоковой структуры литосферы 1-го порядка на участке исследований п. Баяндай - м. Крестовский закономерно выделяются краевые части блока Сибирской платформы и зоны Байкальского рифта (рис. 2, $A$ ). На 2-м уровне иерархии выявлены один центральный блок, Предбайкальская (на северо-западе) и Обручевская (на юго-востоке) межблоковые зоны, из которых два первых структурных элемента являются составляющими Сибирского блока, а третий представляет западное плечо Байкальского рифта. Обручевская зона на более высоком иерархическом уровне включает Морскую, Приморскую и Прихребтовую межблоковые структуры, трассирующиеся из глубин в десятки километров и состоящие из более мелких зон, которые по характеру проявления следует относить к разломным [Семинский и др., 2005].

Поперечные размеры структурных элементов делимости земной коры, отмеченные вдоль полосовидного участка исследований п. Баяндай - м. Крестовский (рис. 2, $A$ ), усреднены по комплексу признаков, причем для каждого из геолого-геофизических полей оценка соответствующего параметра проводилась на основе единого критерия - уровня среднего арифметического (рис. 2, Д). Соотношение поперечных размеров зон и блоков определяется их принадлежностью к структуре более низкого уровня иерархии: на двух смежных уровнях доминируют однотипные структурные элементы делимости (блоки - в блоках, а зоны - в зонах). Так, суммарный вклад Морской, Приморской и Прихребтовой межблоковых зон составляет почти 85 \% от 50-километровой по ширине Обручевской зоны, что оправдывает название «разломная система», иногда используемое для ее определения в литературе [Mats, 1993]. Эта зафиксированная в геолого-геофизических полях аномалия нарушенности, подчеркнутая в приповерхностной части коры эффектом разгрузки напряжений, предстает в качестве гигантского аналога сложнопостроенной сбросовой зоны, обеспечивающей растяжение литосферы в Прибайкалье. Она представляет кайнозойскую форму структурного обновления краевого платформенного шва, который и до этого неоднократно активизировался в течение длительной истории совместного развития Сибирского кратона и Саяно-Байкальского пояса.

Рассмотренные особенности современной зонноблоковой делимости земной коры в области сочленения Сибирской платформы и Саяно-Байкальского подвижного пояса послужили структурной основой для интерпретации результатов гидрогеологических работ, проведенных для полосовидного участка исследований п. Баяндай - м. Крестовский. Главной задачей этих работ было проанализировать распределение, минерализацию и макрокомпонентный состав вод, представ- 


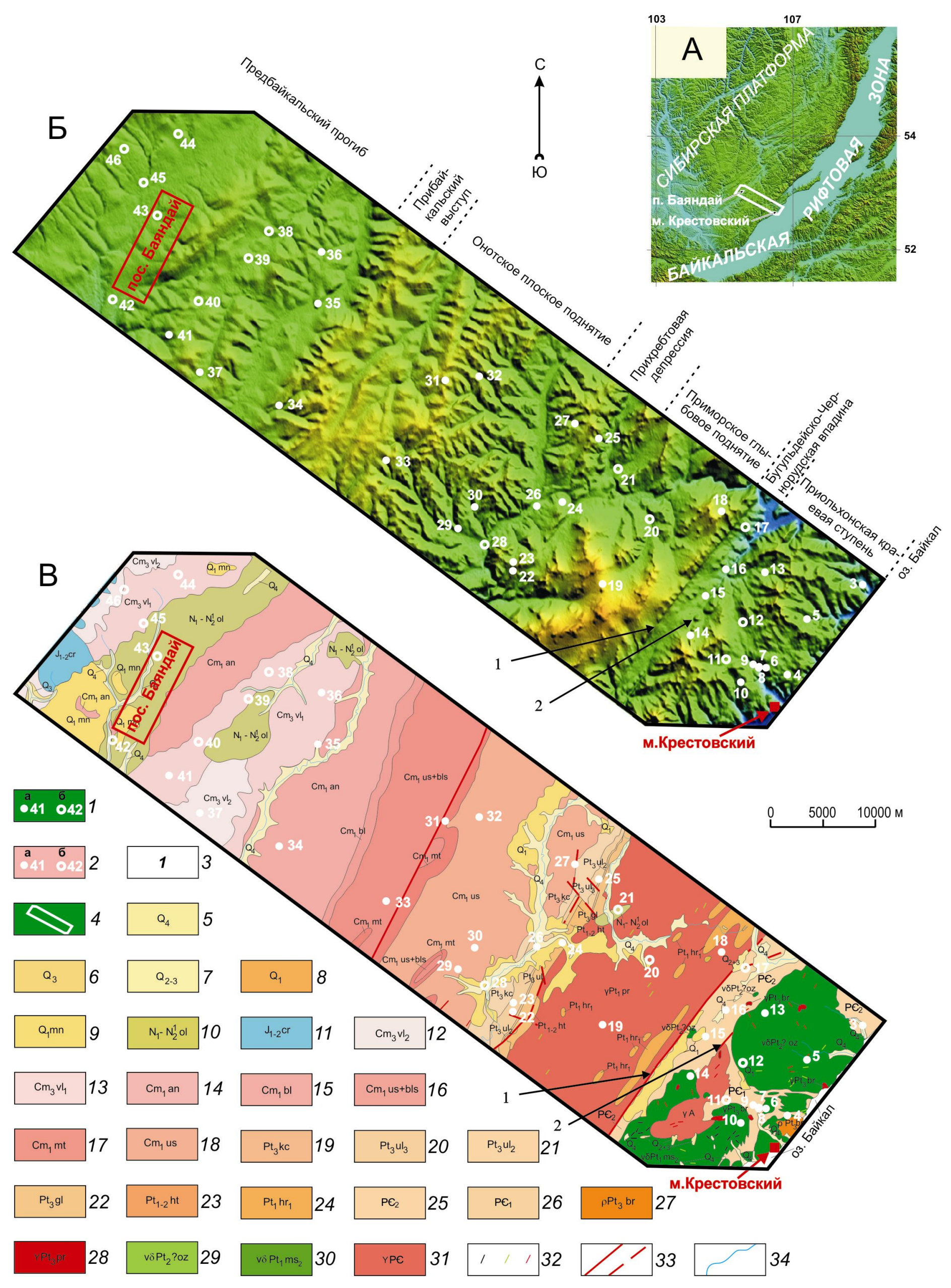


Рис. 1. Геологические и геоморфологические особенности участка комплексных исследований подземной гидросферы в Западном Прибайкалье. $A$ - расположение участка исследований п. Баяндай - м. Крестовский на трехмерной модели рельефа области сочленения Сибирской платформы и Саяно-Байкальского складчатого пояса. $D-B-$ фрагменты трехмерной модели рельефа (Б) и Государственной геологической карты м-ба 1:200000 (B), соответствующие участку исследований п. Баяндай - м. Крестовский. 1-2- расположение родников (а) и скважин (б) на трехмерной модели рельефа (1) и геологической карте (2) участка исследований; 3 - разломные сместители, ограничивающие Бугульдейско-Чернорудский грабен: 1 - Приморский, 2 - Тырганский; 4 - положение участка исследований на обзорной схеме рис. $1, A ; 5-9$ - разнотипные аллювиальные и аллювиально-озерные отложения (четвертичная система): илы, галечники, гравий, пески, суглинки, торфяники и др.; 10 - аллювиально-озерные отложения (миоцен - нижний плиоцен): пески, глины, галечники, ракушняковые известняки; 11 - нижне- и среднеюрские платформенные отложения: песчаники, алевролиты, аргиллиты, конгломераты, пласты угля; 12-18 - разнотипные кембрийские отложения осадочного чехла Сибирской платформы: песчаники, доломиты, известняки, гипс, мергели, гравелиты, алевролиты, глинистые и углисто-глинистые сланцы, каменная соль и др.; 19-22 - разнотипные породы неопротерозоя: кварциты, гравелиты, филлиты, метаморфизованные кварцевые порфиры, углисто-глинистые сланцы, известняки и др.; 23-24-мезо- и палеопротерозойские породы: кварц-мусковитовые, двуслюдяные, мусковитово-гранатовые, хлорит-серицитовые и другие сланцы, матаморфизованные гравелиты, кварциты, порфириты; 25-26 - интенсивно метаморфизованные породы Приольхонья: биотитовые, роговообманковые и другие гнейсы, сланцы, амфиболиты, кристаллические известняки, кварциты; 27-31 - разнотипные интрузивные породы, в т.ч. гранитоиды приморского комплекса (28); 32 - разнотипные дайки; 33 - разломы установленные и предполагаемые; 34 - гидросеть.

Fig. 1. Geology and geomorphology of the site of comprehensive studies of the underground hydrosphere in the Western Pribaikalie. $A$ - Location of the Bayandai - Krestovsky Cape site in the 3D model of the landscape of the junction of the Siberian platform and the Sayan-Baikal folded belt. $5-B$ - Fragments of the 3D model $(B)$ and the State Geological Map, scale 1:200000 (B) that correspond to the Bayandai - Krestovsky Cape site. 1-2 locations of springs (a) and wells (б) in the 3D model (1) and the geological map (2) of the study area; 3 - faults which border the BuguldeikaChernorud graven: 1 - Primorsky, 2 - Tyrgansky; 4 - location of the study area in the generalized scheme shown in Fig. 1A; 5-9-the Quaternary alluvial and alluvial-lacustrine deposits of various types (silt, pebble, gravel, sand, loam, peat etc.); 10 - Miocene - Low Pleistocene alluviallacustrine deposits (sand, clay, pebble, shelly limestone); 11 - the Low and Middle Jurassic platform deposits (sandstone, siltstone, argillite, conglomerate, coal seams); 12-18 - the Cambrian deposits of the Siberian platform cover of various types (sandstone, dolomite, limestone, gypsum, chalky clay, gravel stone, siltstone, clayey and carbonaceous clayey shale, rocky salt etc.); 19-22 - the Neo-Proterozoic rocks of various types (quartzite, gravel stone, phyllite, metamorphosed quartz porphyry, carbonaceous clayey shale, limestone etc.); 23-24 - the Meso- and PaleoProterozoic rocks (quartz-mustovite, binary mica, muscovite garnet, chloritic sericite and other shale, metamorphosed gravel stone, quartzite, porphyrite); 25-26 - intensively metamorphosed rocks of the Priolkhonie (biotite, hornblende and other gneiss, shale, amphibolite, crystalline limestone, quartzite); 27-31 - intrusive rocks of various types, including granitoid of the Primorsky suite (28); 32 - dykes of various types; 33 - confirmed and forecasted faults; 34 - drainage system.

ляющих близповерхностную часть подземной гидросферы изучаемого региона.

\section{3. РЕЗУЛЬТАТЫ ГИДРОГЕОЛОГИЧЕСКИХ ИССЛЕДОВАНИЙ НА УЧАСТКЕ П. БАЯНДАЙ - М. КРЕСТОВСКИЙ}

Фактическим материалом для анализа послужили результаты опробования подземных вод в 46 точках изучаемой полосы (см. рис. 1). Собранный банк данных является для нее практически полным, поскольку объединяет фондовые материалы Государственной гидрогеологической съемки м-ба 1:200000 [Гуссау, Исаченко, 1961; Еремченко, Вьюн, 1961; Блохин, 1966; Блохин, Исаченко, 1962] и результаты собственных исследований. Последние, кроме сбора дополнительной гидрогеологической информации, позволили посредством переопробования источников подземных вод территории подтвердить возможность совместного использования данных полного химического анализа воды, полученных в разное время разными лабораториями (для собственных проб - это гидрогеохимическая лаборатория Института земной коры СО РАН). Сопоставление данных по 46 точкам опробования (см. рис. 1) с фондовыми материалами, полученными в ходе гидрогеологической съемки более обширной территории [Гуссау, Исаченко, 1961; Еремченко, Вьюн, 1961; Нечаева, Распутин, 1961; Блохин, 1966; Блохин,
Исаченко, 1962; Аликин, Бачин, 1965; Кауров, 1965, Бондаренко, 1971; Борисенко и др., 1971; БурдуковСкий и др., 1982; Бурдуковский, Еремченко, 1975; Скуратовский, 1975], свидетельствует, что выбранный для детальных исследований участок п. Баяндай - м. Крестовский позволяет составить представление об основных гидрогеологических особенностях подземных вод Западного Прибайкалья в целом.

Следует отметить, что результаты предыдущих исследований гидрогеологических условий Прибайкалья [Пиннекер и др., 1968] в целом подтвердились в ходе изучения минерализации, состава и температуры подземных вод на изучаемой территории. По типу это пресные воды средне- и предгорных районов главным образом поверхностного происхождения, в анионном составе которых преобладает гидрокарбонат-ион, а среди катионов - кальций, магний и, реже, калий и натрий. С другой стороны, материалы, полученные нами для участка детальных исследований, позволили углубить эти представления и сделать общий вывод об определяющей роли структурно-тектонического фактора в формировании состава подземных вод. Связующим звеном в этом плане является рельеф, так как для горно-складчатых областей в целом [Степанов, 1959, 1989] и для территории Западного Прибайкалья в частности [Пиннекер и др., 1968; Павлов, 2000] известна общая зависимость основных гидрогеологических осо- 



бенностей подземных вод от морфологии рельефа и соответствующих ему ландшафтов.

Результаты собственных исследований минерализации, состава подземных вод и распределения их естественных выходов, подтверждающие сделанный вывод, представлены ниже.

Основные скопления естественных выходов подземных вод, составляющих практически 70 \% опробованных точек на изучаемой территории (рис. $1, B-B$; рис. $2,5-B$ ), вытянуты в северо-восточном направлении и приурочены к впадинам, представляющим приразломные грабены (Бугульдейский грабен, Прихреб- товая депрессия). Как следствие этого, родники в целом тяготеют к Обручевской разломной системе, где рассматриваемые структуры составляют основу межблоковых зон и, наряду с высокими поднятиями (Приморское), присутствуют гипсометрически опущенные блоки (Приольхонская ступень). Дополнительным фактором, обусловливающим большую плотность родников на рассматриваемом участке, является его повышенная нарушенность разломами, которая увеличивает проницаемость горного массива в пределах тектонически активного Байкальского рифта по отношению к Предбайкальскому прогибу, занимающему 
Рис. 2. Результаты геолого-геофизических исследований, отражающих зонно-блоковую структуру земной коры области сочленения Сибирской платформы и Саяно-Байкальского складчатого пояса в Западном Прибайкалье (по [Семинский и др., 2010] с упрощениями). $A$ - иерархия зон и блоков, согласно результатам геолого-геофизических исследований. 5 - границы основных геоморфологических подразделений на профиле п. Баяндай - м. Крестовский. $B$ - схематизированный геологический разрез верхней коры по профилю п. Баяндай - м. Крестовский (на основе Государственной геологической карты м-ба 1:200000 и данных А.В. Черемных). $Г$ - геоэлектрический разрез верхней коры по профилю п. Баяндай - м. Крестовский, составленный по данным магнитотеллурических зондирований (Е.В. Поспеева, ИНГГ СО РАН). Д - вариации плотности спрямленных элементов рельефа $(D)$, объемной активности радона $(Q)$ и потенциала естественного электрического поля $(U)$ вдоль профиля п. Баяндай - м. Крестовский. 1 - аллювиально-озерные отложения (пески, глины, галечники и др.); 2 - породы верхней части осадочного чехла платформы (песчаники, доломиты, известняки, алевролиты, углисто-глинистые сланцы, каменная соль и др.); 3 - породы более глубоких горизонтов платформенного чехла (кварциты, метаморфизованные кварцевые порфиры, известняки и др.); 4 - метаморфизованные породы складчатого пояса (разнотипные гнейсы и сланцы, амфиболиты, кристаллические известняки, кварциты и др.); 5-6 интрузии гранитов (5) или габбро, габбро-диориты, диоритовые порфиры и др. (6); 7 - крупные и более мелкие разломы; 8 - изолинии значений удельного электрического сопротивления, Ом·м; 9 - контуры участков с низким сопротивлением; 10 - аномальные значения параметров, отличающиеся в большую (для $D$ и $Q$ ) или меньшую (для $U$ ) сторону от среднего арифметического (красный пунктир).

Fig. 2. Results of geological and geophysical studies showing the crustal zone-block structure of the junction of the Siberian platform and the SayanBaikal folded belt in the Western Pribaikalie (according to [Семинский и др., 2010], simplified). $A$ - the hierarchy of the zones and blocks according to the results of geological and geophysical studies. $E$ - boundaries of the geomorphological subdivisions in the Bayandai - Krestovsky Cape profile. $B$ - the schematic geological profile of the crust along the the Bayandai - Krestovsky Cape profile (based the State Geological Map, scale 1:200000 and data provided by A.V. Cheremnykh). $\Gamma$ - the geoelectrical profile of the upper crust along the the Bayandai - Krestovsky Cape profile (based on MTS data provide by E.V. Pospeeva, Institute of Petroleum Geology and Geophysics SB RAS). Д- variations of density of straightened landscape elements $(D)$, volume activity of radon $(Q)$ and natural electric field potential $(U)$ along the the Bayandai - Krestovsky Cape profile. 1 alluvial-lacustrine deposits (sand, clay, pebble etc.); 2 - rock of the upper part of the sedimentary cover of the platform (sandstone, dolomite, limestone, silt, carbonaceous clayey shale, rocky salt etc.); 3 - rocks of the deeper horizons of the platform cover (quartzite, metamorphosed quartz porphyry, limestone etc.); 4 - metamorphosed rocks of the folded belt (gneiss and shale of various types, amphibolite, crystalline limestone, quartzite etc.); 5-6 intrusions of granites (5) or gabbro, gabbro-diorite, diorite porphyre etc. (6); 7 - large and smaller faults; 8 -isolines of specific electrical resistivity values, Omm; 9 - contours of areas with low electric resistance; 10 - anomalous values of parameters which are higher (for $D$ and $Q$ ) or lower (for $U$ ) than corresponding average arithmetical values (red dotted line).

северо-западную часть площади исследований.

Минерализация подземных вод $(M)$ ввиду ее обратной зависимости от высоты рельефа, напротив, имеет высокие значения на северо-западной половине территории и крайнем юго-востоке (рис. $3, A-D$ ). Параметр $M$ в целом возрастает от границы Обручевской межблоковой зоны в глубь платформы, достигая в Предбайкальском прогибе уровня 0.85 г/дм³ (воды - гидрокарбонатные со смешанным составом катионов). Для противоположной краевой части изучаемой территории также характерны повышенные значения общей минерализации (до 1 г/дм ${ }^{3}$ ) и гидрокарбонатный магниево-кальциевый состав вод, что обусловлено относительно низким гипсометрическим положением Приольхонской ступени, сложенной древними метаморфитами (мраморы, сланцы, гнейсы, и др.). Между этими участками выделяется представленный гранитоидами Приморский хребет, подземные воды которого характеризуются гидрокарбонатным натриево-кальциевым составом и крайне низким уровнем минерализации (до 0.2 г/дм $\left.{ }^{3}\right)$.

Наличие отмеченной закономерности, а также отсутствие резких скачков величины минерализации при переходе от одного водопроявления на изучаемой территории к другому позволяют использовать при дальнейшем анализе карту пространственного распределения параметра $M$ в изолиниях. Как видно из рис. $3, \bar{E}$, на фоне общей тенденции увеличения минерализации в обе стороны от участка минимальных значений в от- дельных местах рассматриваемой территории наблюдаются локальные максимумы величины $M$. Их оси вытянуты в северо-восточном направлении, а положение и размеры соответствуют выделенным ранее межблоковым зонам 3-го иерархического уровня. Максимум, морфологически приуроченный к Прибайкальскому выступу (см. рис. $2,5-B)$, кардинально не нарушает отмеченную закономерность, так как, скорее всего, обусловлен сравнительно небольшими разломными структурами, не образующими в совокупности межблоковой зоны рассматриваемого уровня иерархии [Семинский и др., 2010]. Повышение значений параметра $M$ в межблоковых зонах по сравнению с окружающими участками земной коры определяется их большей тектонической активностью и, следовательно, нарушенностью субстрата, который подвергается интенсивному выветриванию с образованием глубоких линейно-эрозионных форм. Следовательно, рассматриваемые тектонические зоны являются аномалиями в отношении условий водообмена.

Сделанные выводы в целом подтверждаются представленными ниже результатами анализа макрокомпонентного состава подземных вод.

Анионный состав подземных вод в этом плане должен рассматриваться в первую очередь, поскольку он в большей степени характеризует условия водообмена [Пиннекер и др., 1968]. В то же время, судя по диаграмме Ферре (рис. $4, A$ ), подземные воды участка исследований не отличаются разнообразием по соотно- 
K.Zh. Seminsky, M.A. Tugarina: Results of comprehensive studies of the underground hydrosphere...

A

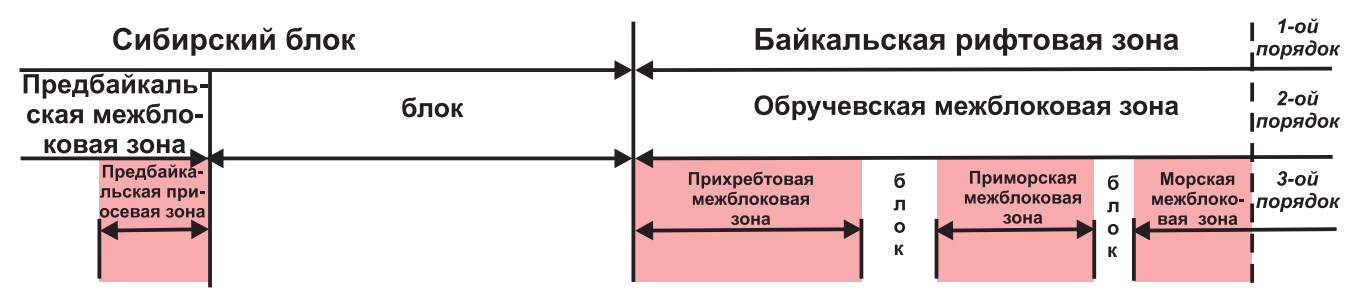

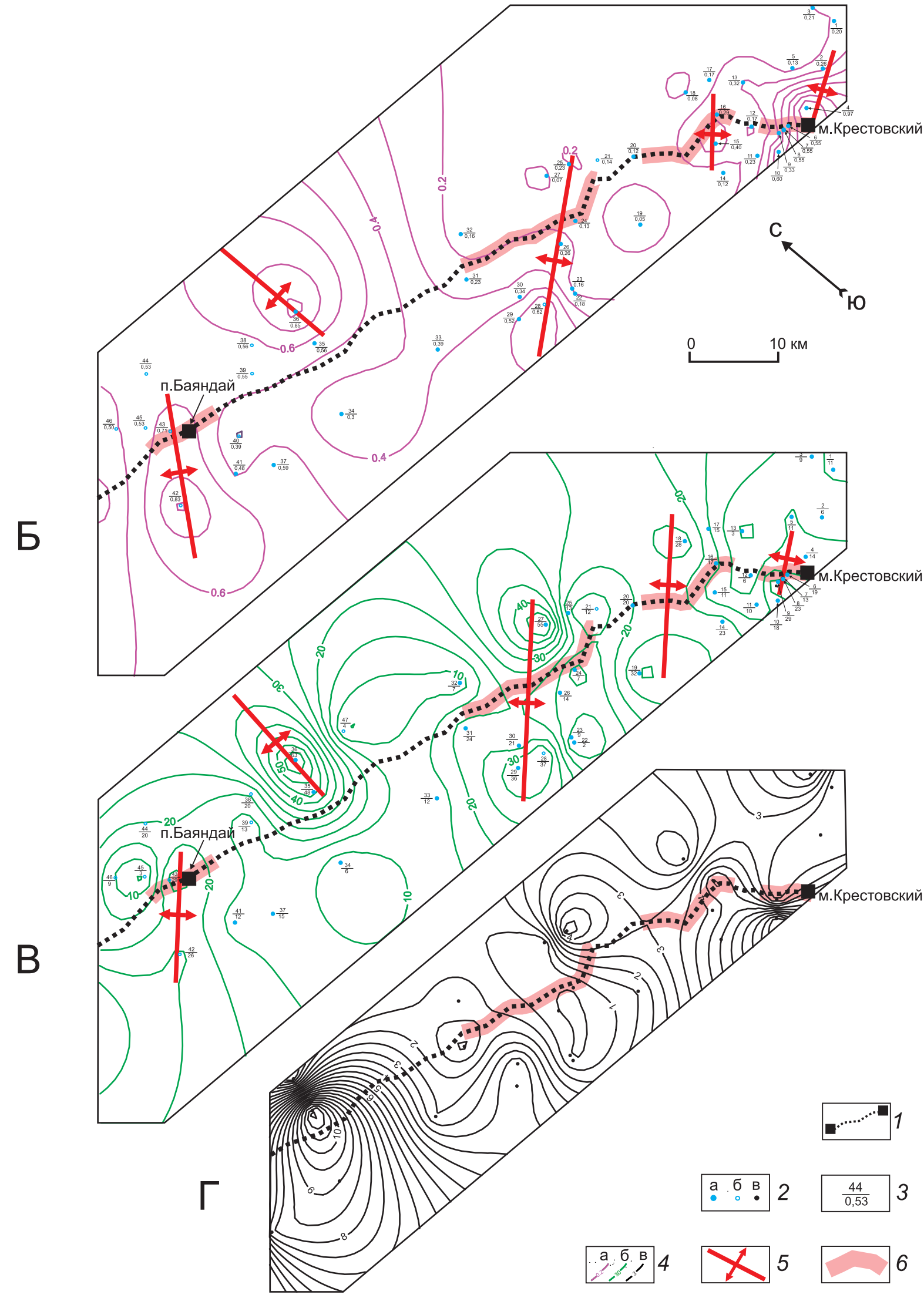


Рис. 3. Результаты гидрогеологических работ на участке исследований п. Баяндай - м. Крестовский. $A-$ иерархия зон и блоков, согласно результатам предыдущих геолого-геофизических исследований [Семинский и др., 2010]. 5 - карта распределения общей минерализации $(M)$ подземных вод в изолиниях. $B$ - карта распределения параметра $H$ (содержание в пробе воды суммы сульфат- и хлор-ионов в \%эквивалентах) в изолиниях. $\Gamma$ - карта распределения температуры подземных вод в изолиниях (по естественным выходам). 1 - положение профиля предыдущих геолого-геофизических работ; 2 - положение опробованных скважин (а) и родников (б), в т.ч. - с измерением температуры (в); 3 - индексы водопроявлений (вверху - номер; внизу - значения параметров $M$ для рис. 5 или $H$ для рис. $B$ ); $4-$ изолинии значений $M(\mathrm{a}), H(б)$ и температуры (в) воды; 5 - простирание осей для условных полос максимальных значений $M$ или $H$; 6 - участки профиля п. Баяндай - м. Крестовский, принадлежащие межблоковым зонам 3-го порядка по данным геолого-геофизических исследований [Семинский и др., 2010].

Fig. 3. Results of hydrogeological studies of the Bayandai - Krestovsky Cape profile. $A$ - the hierarchy of the zones and blocks according to results of geological and geophysical studies published in [Семинский и др., 2010]. $Б$ - the general underground water mineralization $(M)$ map. $B-$ the parameter $H$ (percentage of the sum of sulphate- and chlorine-ions contained in water samples) map. $\Gamma$ - the underground water temperature map (based on data from natural discharge sites). 1 - the profile of the previous geological and geophysical studies; 2 - locations of tested wells (a) and springs (б), including temperature measurement points (в); 3 - water show indices (top - number; bottom - values of parameter $M$ in Fig. 5 or $H$ in Fig. $B$ ); 4 - isolines of values of $M(\mathrm{a}), H(б)$ and temperature (в) of water; 5 - strikes of axes in conditional bands of maximum $M$ or $H$ values; 6 sections of the Bayandai - Krestovsky Cape profile that belong to inter-block zones of the $3^{\text {rd }}$ order, according to results of geological and geophysical studies published in [Семинский и др., 2010].

шениям основных анионов. Это почти исключительно гидрокарбонатные воды (тип I), кроме шести водопроявлений, в трех из которых наряду с гидрокарбонатами присутствует хлор (тип II), в двух - сульфат-ион (тип III) и в одном (тип IV) - оба компонента. Как видно из схемы распределения выделенных типов вод (рис. 4, Б), этот традиционный способ анализа позволяет наметить лишь слабую тенденцию маркирования водами с уменьшенным содержанием гидрокарбонат-иона участков земной коры, нарушенных разломами. Выходы хлорсодержащих и смешанных вод приурочены, соответственно, к Приморской и Прихребтовой межблоковым зонам 3-го порядка, тогда как сульфатные водопроявления располагаются в пределах небольшого изометричного участка Прибайкальского выступа, для которого ранее отмечалось повышение общей минерализации.

Вместе с тем, полученный результат важен в двух отношениях. Во-первых, он свидетельствует, что для участка исследований справедлива общая закономерность, установленная ранее для небольших озер Приольхонья [Склярова и др., 2004] и подземных вод Западного Прибайкалья в целом [Пиннекер и др., 1968]: уменьшение гидрокарбонат-иона (и, соответственно, увеличение суммы анионов сульфат-иона и хлора) отражает ухудшение условий водообмена в пределах структурно осложненных участков. Во-вторых, смежные водопроявления имеют близкие соотношения анионов, что позволяет использовать для дальнейшего анализа карты распределения рассматриваемых компонентов в изолиниях.

В связи с этим информативной для дальнейшего анализа является карта распределения параметра $H$, представляющего сумму сульфат- и хлор-ионов $\left(\mathrm{SO}_{4}^{-2}+\mathrm{Cl}^{-}\right)$, которая выражена в \%-эквивалентах с целью снижения влияния вещества при изучении состава воды. Как видно из рис. $3, B$, низкие значения параметра $H$ (и, соответственно, высокие содержания гид- рокарбонат-иона) характерны для блоков, тогда как межблоковые зоны в этом отношении являются аномалиями. Гидрокарбонат-ион преобладает в составе вод их юго-восточных участков (см. рис. 3, $B$; точки № 22-26 и № 15-17), которые в структурном отношении представляют наиболее нарушенные и, как следствие этого, глубокопроницаемые висячие крылья крупных сбросов (Прихребтового и Приморского). Максимумы содержаний сульфат-иона и хлор-иона, напротив, маркируют северо-западные части межблоковых зон, где ввиду меньшей плотности оперяющих разрывов водообмен затруднен (см. рис. $3, B$; точки № 27-30 и № 18-19). Это известное в гидрогеологии различие степени обводненности висячего и лежачего крыльев разлома является дополнительным подтверждением справедливости вывода о структурном контроле водообмена на рассматриваемой территории.

Катионные соотношения в составе изученных вод характеризуются на участке исследований бо́льшим разнообразием (рис. 5). При этом водопроявления с однотипными соотношениями катионов (группы IVIII) располагаются на участке исследований, как правило, рядом друг с другом (рис. 5, Б). Еще более отчетливо данная особенность проявляется, если объединить близкие группы в более крупные типы и учесть, что к каждому из них могут относиться воды группы II, как переходные по составу (пунктирные контуры на рис. $5, A$ ). С юго-востока на северо-запад отчетливо выделяются участки доминирования магниево-кальциевых (Приольхонский), натриево-калиево-кальциевых (Приморский), магниево-кальциевых (Онотский) и смешанных (Предбайкальский) по составу катионов вод (рис. 5, Б). Сравнение этой латеральной зональности с геологической картой (см. рис. 1, B) показывает связь состава подземных вод с разновидностями горных пород, обнажающимися на поверхности. Особенно отчетливо это проявляется для Приольхонского и Онотского участков, причем в по- 


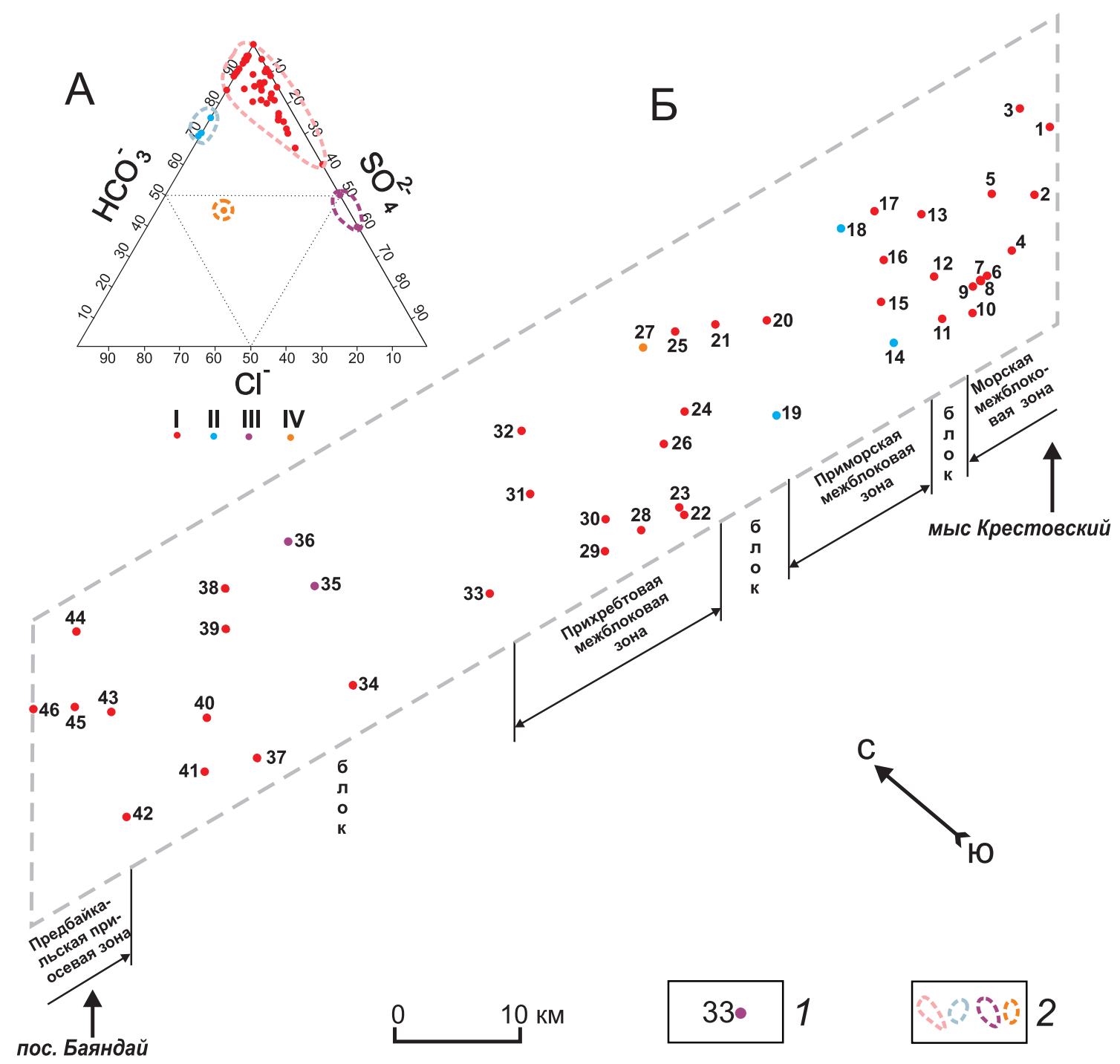

Рис. 4. Разделение водопроявлений по анионному составу на основе диаграммы Ферре $(A)$ и распределение водопроявлений разного типа на участке исследований п. Баяндай - м. Крестовский $(Б) .1$ - положение и номер водопроявления, а также его тип (цвет кружка и римская цифра) в соответствии с составом анионов (см. рис. $A$ ); 2 - области на диаграмме Ферре (рис. $A$ ), включающие водопроявления с близким анионным составом.

Fig. 4. Classification of water shows by anion composition on the basis of the Ferre diagram $(A)$, and distribution of water shows varying in types in the Bayandai - Krestovsky Cape site $(B) .1$ - location, number and type of a water shows according to its anion composition (see Fig. A); $2-$ areas in the Ferre diagram (Fig. $A$ ), including water shows with similar anion composition.

следнем случае даже внутренняя зональность, выражающаяся преобладанием кальциевых вод на северозападе и магниевых на юго-востоке, обусловливается сменой в этом направлении свит, в составе которых, с одной стороны, доминируют известняки и гипс, а с другой - доломиты. Менее однородным в рассматриваемом отношении является Приморский участок, но и для него преобладают калиево-натриевые воды, формирующиеся в гранитоидах приморского комплекса.

Более отчетливо представленные закономерности иллюстрируют карты распределения процентного содержания каждого из катионов в изолиниях (рис. $6, \bar{b}$ $\Gamma)$. Так, взаимосвязь с породными комплексами отра- жают площади максимумов $\mathrm{Ca}^{2+}, \mathrm{Mg}^{2+}$ и $\mathrm{Na}^{+}+\mathrm{K}^{+}$, для оконтуривания которых уровни значений были подобраны так, чтобы заполнить без существенных перекрытий весь участок исследований (рис. 6, $A$ ). Более того, границы этих участков, как правило, располагаются в пределах выделенных ранее аномалий водообмена (см. рис. 3, B). Таким образом, разные показатели макрокомпонентного состава подземных вод в большей или меньшей степени отражают положение широких нарушенных зон и контактирующих по ним блоков, т.е. специфику структурной делимости земной коры изучаемого региона.

Заканчивая описание гидрогеологических данных, 
необходимо отметить, что температурные особенности подземных вод не отличаются большим разнообразием: на исследуемой площади преобладают холодные подземные воды с температурой $(T)$, составляющей в среднем 3-7 ${ }^{\circ} \mathrm{C}$. Распределение $T$ в меньшей степени, чем какая-либо другая из рассмотренных характеристик, отражает наличие на участке исследований п. Баяндай - м. Крестовский проницаемых межблоковых зон (см. рис. 3, Г). Это, с одной стороны, подтверждает поверхностное происхождение подземных вод, а с другой - может быть следствием объективного недостатка фактического материала, проявляющегося, в частности, в отсутствии единообразия измерений $T$, проведенных в разное время.

Установленные закономерности по большому счету можно отнести ко всей территории Западного Прибайкалья, так как особенности ее строения в полной мере представляет полосовидный участок п. Баяндай м. Крестовский. Его основные морфотектонические подразделения трассируются на северо-восток и югозапад [Уфимцев, 1992; Перевозников, 1999], обусловливая для обширной области плеча Байкальского рифта (и смежной платформенной территории) распределение, минерализацию и состав подземных вод, а также озер, так как, согласно работе [Склярова и др., 2004], именно тектоника играет главную роль в гидрогеохимии водопроявлений данного типа.

Главным итогом представленных гидрогеологических исследований является вывод о том, что активная зонно-блоковая структура земной коры через специфику рельефа и нарушенности горного массива при прочих равных условиях определяет особенности близповерхностной части гидросферы рассматриваемого региона. На низком уровне иерархии в качестве отчетливого гидрогеологического рубежа выступает северо-западная граница Обручевской межблоковой зоны, которая представляет структуру краевого шва Сибирской платформы, активизированного на современном этапе тектогенеза. Эта граница отделяет слабоминерализованные и пресные воды платформенного блока от ультрапресных и пресных вод горной области. В пределах упомянутых структурных подразделений выделяются Предбайкальская, Прихребтовая, Приморская и Морская межблоковые зоны, которые на данном уровне иерархии контролируют положение соответствующих аномалий по режиму водообмена, общей минерализации и степени обводненности. Особенности строения этих аномалий определяются наличием межблоковых зон разломного уровня иерархии, которые, в свою очередь, состоят из разноранговых тектонических нарушений, являющихся в зависимости от специфики внутренней структуры непроницаемыми упорами или каналами для миграции флюидов.

Вещественная специфика горного массива, определяющая состав выносимых компонентов, осложняет проявление ведущей роли структуры земной коры при формировании подземных вод в межблоковых зонах.
Вследствие влияния вещества отдельные характеристики подземных вод по-разному отражают зонноблоковую делимость конкретного региона, что ранее отмечалось и в отношении разнотипных геофизических полей [Семинский и др., 2010]. Так, суммарное содержание сульфат- и хлор-ионов (или, наоборот, гидрокарбонат-иона), указывающее на условия водообмена (см. рис. $3, B$ ), в отличие от параметра общей минерализации (см. рис. 3, Б), в полной мере отражает зонно-блоковую структуру Западного Прибайкалья, выявленную ранее по комплексу геолого-геофизических признаков. Различиями катионных соотношений, наиболее подверженных влиянию породных комплексов, выделяются объемы блоков, которые при тектоническом контактировании обычно отличаются по петрографическому составу.

\section{4. ОСОБЕННОСТИ ПОДЗЕМНОЙ ГИДРОСФЕРЫ ЗАПАДНОГО ПРИБАЙКАЛЬЯ ПО ДАННЫМ КОМПЛЕКСНЫХ ИССЛЕДОВАНИЙ}

Более глубокие уровни подземной гидросферы отражаются на геоэлектрическом разрезе (см. рис. 2, $Г$ ), построенном Е.В. Поспеевой (Институт нефтегазовой геологии и геофизики СО РАН). Выделяющиеся на нем аномалии проводимости характеризуются значительными размерами, плавными границами, слабой анизотропией и градиентами поля, что на более представительном фактическом материале подтверждает мнение предшественников [Попов, 1987; Berdichevsky et al., 1999] о флюидной природе подобных зон и слоев в литосфере Байкальского рифта. Более того, судя по рис. 2, $\Gamma$, верхняя кора в регионе интенсивно нарушена и обводнена, так как обычно характерные для соответствующих глубин значения удельного электрического сопротивления - 1000-10000 Ом·м - распространены здесь локально и тяготеют главным образом к северозападной части геоэлектрического разреза. Его же юго-восточная половина представляет Обручевскую разломную систему, где участки упомянутых высоких сопротивлений несопоставимо малы по сравнению с объемами флюидизированной коры. Таким образом, эта межблоковая зона 2-го порядка может быть отождествлена с субвертикальным флюидизированным каналом, выделенным М.Н. Бердичевским и др. [1999]. Судя по предложенной в цитированной статье мелкомасштабной геоэлектрической модели (рис. 7), зона проникает в верхнюю мантию и вместе с аналогичной структурой в Восточном Прибайкалье контролирует развитие Байкальского рифта.

Геоэлектрический разрез (рис. 2, Г) детализирует зонно-блоковое строение Обручевской разломной системы и краевой части смежного платформенного блока. Проводящие участки представляют флюидные системы межблоковых зон 3-го порядка, распространяющиеся до глубин в 10 км и более. В их газово-жидком 


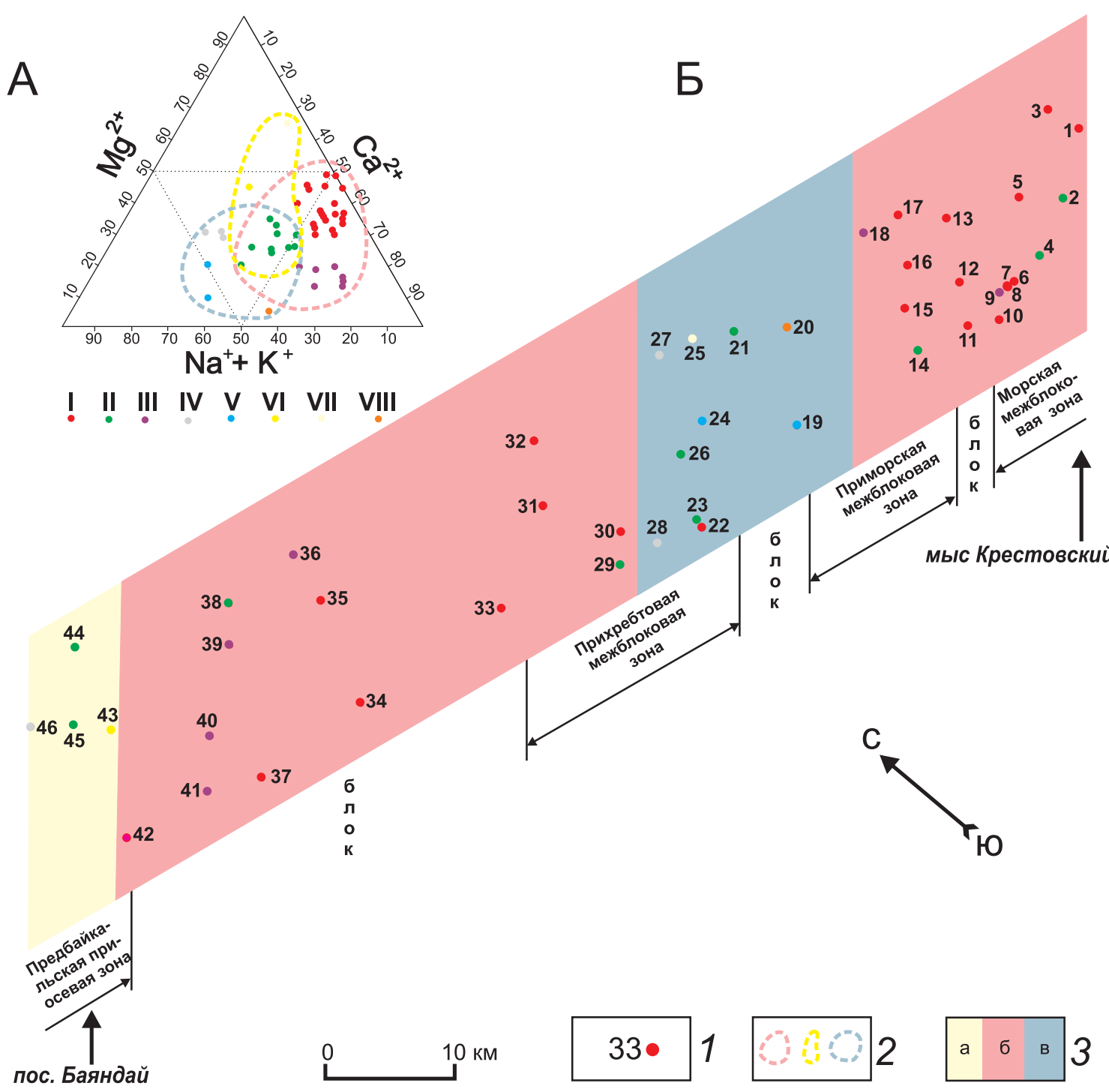

Рис. 5. Разделение водопроявлений по катионному составу на основе диаграммы Ферре $(A)$ и распределение водопроявлений разного типа на участке исследований п. Баяндай - м. Крестовский (b). 1 - положение и номер водопроявления, а также его тип (цвет кружка и римская цифра) в соответствии с составом катионов (см. рис. $A$ ); 2 - области на диаграмме Ферре (рис. $A$ ), включающие водопроявления с близким анионным составом; 3 - области на рис. 5 , в пределах которых преобладают однотипные по катионному составу подземные воды: а смешанного типа; б - магниево-кальциевые; в - натриево-калиево-кальциевые.

Fig. 5. Classification of water shows by basis ion composition on the basis of the Ferre diagram $(A)$, and distribution of water shows varying in types in the Bayandai - Krestovsky Cape site $(B) .1$ - location, number and type of a water shows according to its basis ion composition (see Fig. $A$ ); 2 - areas in the Ferre diagram (Fig. $A$ ), including water shows with similar anion composition; 3 - areas in Fig. $E$ with dominant underground waters of similar basis ion composition: a - mixed type; 6 - magnesium-calcium; в - sodium-potash-calcium.

составе присутствуют разнотипные проводящие компоненты, о чем свидетельствуют достаточно низкие (до 4 Ом·м) значения удельного сопротивления. Как видно из рис. $2, A, \Gamma$, и $3, A, B$, проводящие участки пространственно совпадают с аномалиями водообмена, но, судя по отличию размеров, по-разному. В предбайкальской части исследованной полосы наблюдается практически полное совпадение. Для Морской зоны, несмотря на дефицит гидрогеологических данных, также можно говорить об удовлетворительном соот- ветствии. Поперечные размеры разнотипных аномалий, приуроченных к Прихребтовой зоне, примерно одинаковы за исключением верхней части геоэлектрического разреза (до глубины 3 км), где зона пониженных сопротивлений уменьшается почти вполовину. Наибольшие отличия характерны для Приморской межблоковой зоны, которая полноценно проявлена в гидрогеологических признаках и лишь локально - низкими значениями удельного сопротивления.

В целом проведенное сопоставление показало, что 


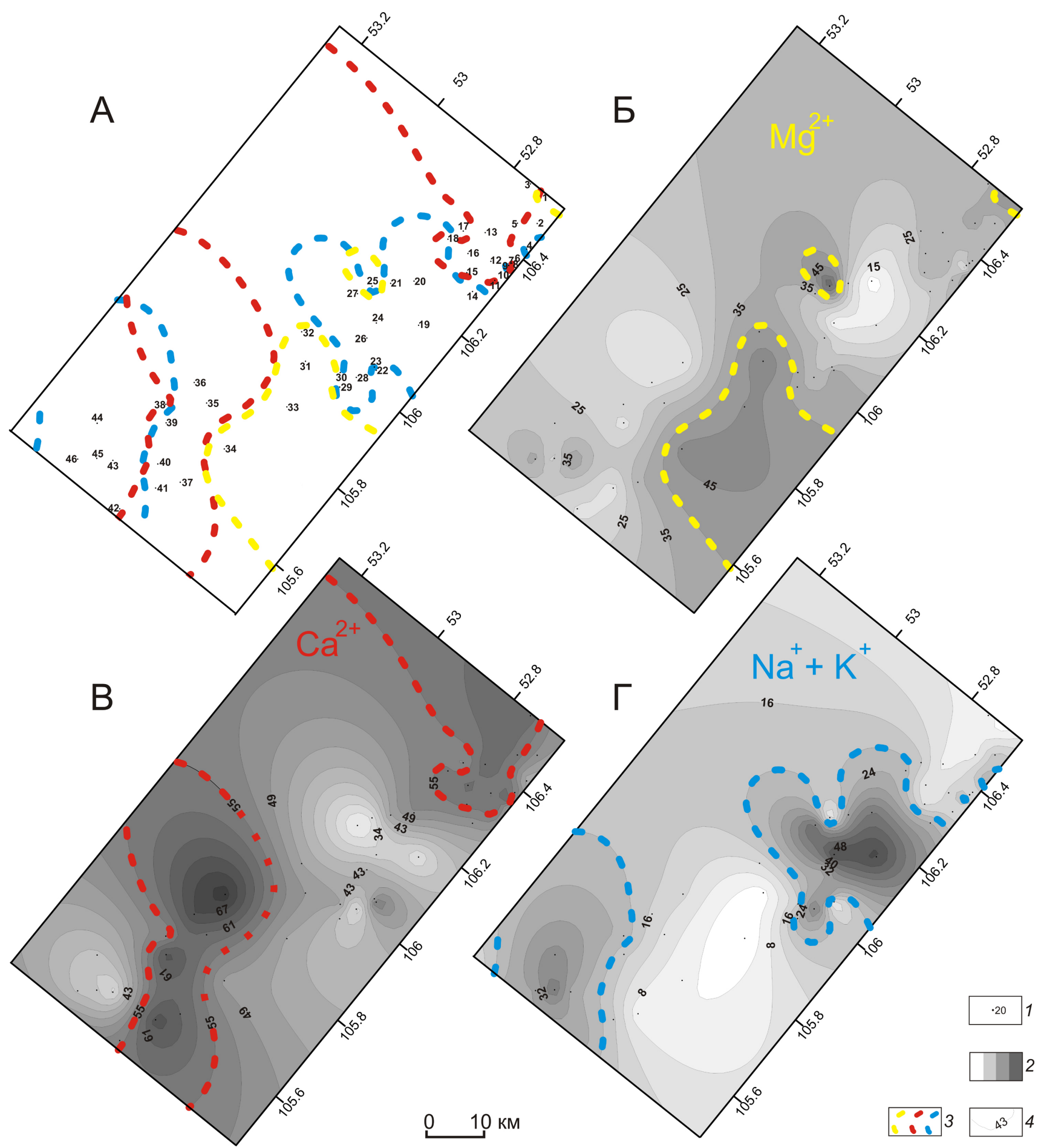

Рис. 6. Карты распределения в изолиниях процентного содержания основных катионов в подземных водах участка исследований. $A-$ сводная карта, на которой желтым, красным и синим пунктирами показаны области максимальных содержаний, соответственно, Мg ${ }^{2+}$, $\mathrm{Ca}^{2+}$ и $\mathrm{Na}^{+}+\mathrm{K}^{+}$, согласно положению изолиний на картах $5-\Gamma$. $Б-\Gamma-$ карты распределения в изолиниях процентного содержания катионов $\mathrm{Mg}^{2+}(b), \mathrm{Ca}^{2+}(B)$ и $\mathrm{Na}^{+}+\mathrm{K}^{+}(I)$ на участке исследований. 1 - положение водопроявлений на всех картах и их порядковый номер (на рис. $A) ; 2$ - области, в пределах которых значение рассматриваемого на карте параметра меняется в определенных пределах, соответствующих уровням ограничивающих изолиний; 3 - изолинии, оконтуривающие области максимальных содержаний катионов $\mathrm{Mg}^{2+}(b), \mathrm{Ca}^{2+}(B)$ и $\mathrm{Na}^{+}+\mathrm{K}^{+}(\Gamma)$ в составе подземных вод; $4-$ изолинии одинаковых содержаний катионов.

Fig. 6. The map of basis ion contents (in percentage values) of underground waters in the study area. $A$ - the summary map showing areas of maximum contents of $\mathrm{Mg}^{2+}, \mathrm{Ca}^{2+}$ и $\mathrm{Na}^{+}+\mathrm{K}^{+}$(delineated by yellow, red and blue dotted lines, correspondingly), according to positions of the isolines in the maps on Fig. $5-\Gamma$. $Б-\Gamma-$ maps of distribution of $\mathrm{Mg}^{2+}\left(\right.$ Б), $\mathrm{Ca}^{2+}(\mathrm{B})$ и $\mathrm{Na}^{+}+\mathrm{K}^{+}(\Gamma)$ (in percentage values) in the study area. $1-$ locations of water shown in all the maps and their numbers (in Fig. $A$ ); 2 - areas wherein the values of the parameter under study range within the limits corresponding to the levels of bounding isolines; 3 - isolines delineating the areas of maximum contents of basis ion of $\mathrm{Mg}^{2+}(B), \mathrm{Ca}^{2+}(B)$ and $\mathrm{Na}^{+}+\mathrm{K}^{+}(I)$ in the underground water composition; 4 - isolines showing equal contents of basis ions. 


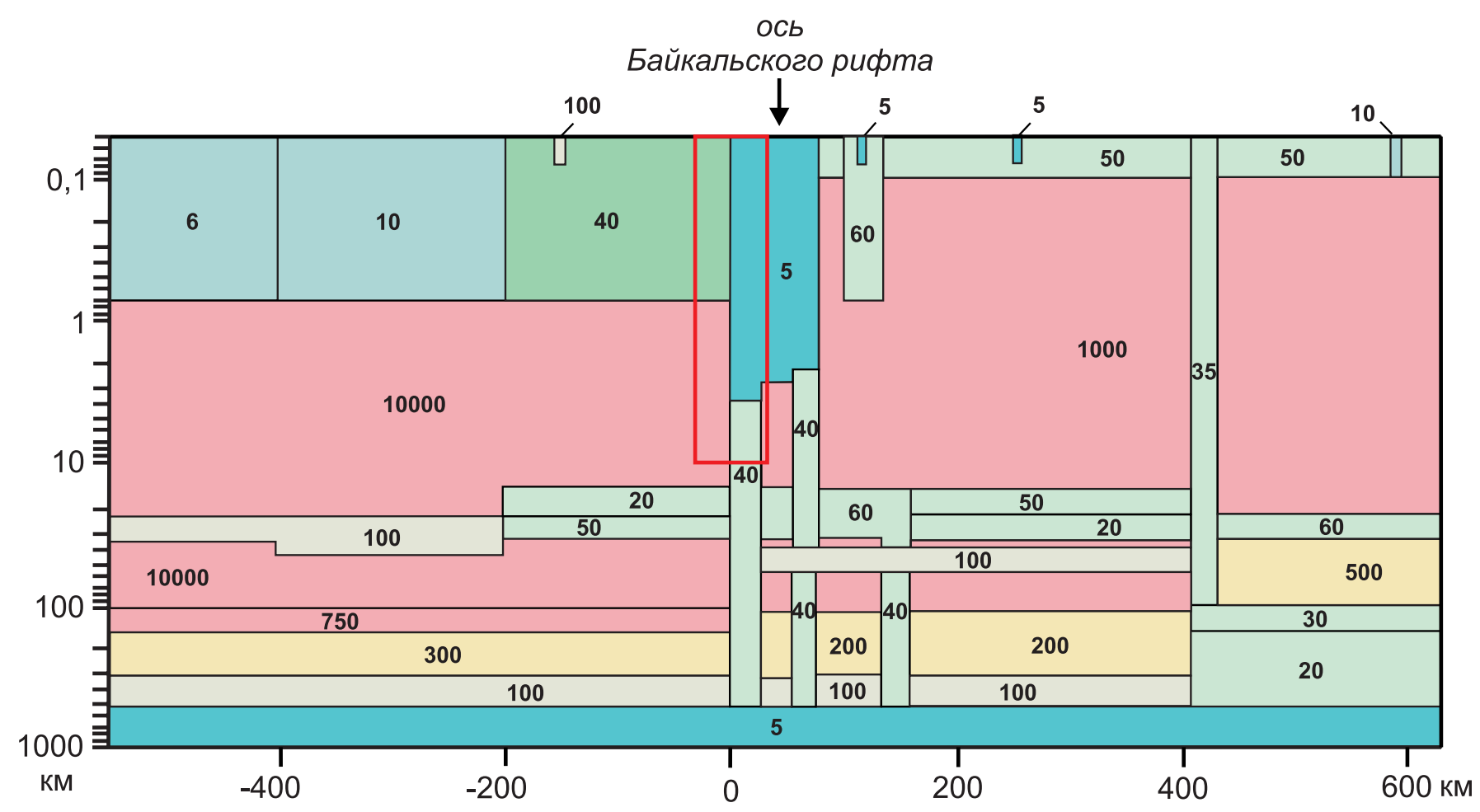

Рис. 7. Глубинный геоэлектрический разрез, построенный М.Н. Бердичевским с соавторами [Berdichevsky et al., 1999] для модели Байкальского рифта типа «Мантийный диапир» (с вертикальными проводящими каналами), наиболее удовлетворяющей магнитотеллурическим данным. Красный прямоугольник - примерное положение геоэлектрического разреза, представленного на рис. 2, Г. Цветом показаны области с примерно одинаковыми электропроводящими свойствами, а цифрами - значения удельного электрического сопротивления (Ом·м).

Fig. 7. The depth geoelectrical profile of the Baikal rift. The profile was compiled by M.N. Berdichevsky and co-authors [1999] for the «mantle diapir» model (with vertical conducting channels) that properly meets the available set of magneto-telluric data. The red triangle shows approximately the location of the geoelectrical profile given in Fig. 2, $\Gamma$. Colours denote areas with roughly equal electrical conductivity properties. Numbers show values of specific electrical resistivity (Omm).

глубинные аномалии проводимости выражены на поверхности нарушенными обводненными зонами. Обнаруженные несоответствия объясняются близповерхностным характером вод, изученных в Западном Прибайкалье общепринятыми гидрогеологическими методами. Это не противоречит данным предшественников о проникновении метеорных вод в земную кору Байкальского рифта на первые километры [Голубев, 1988] и даже десятки километров [Pinneker et al., 1998]. В настоящее время, наряду с изливом вод на дневную поверхность, их существенная часть может уходить по зонам крупных разломов на глубину, мигрировать и, согласно работе [Голубев, 1988], разгружаться в прибрежной зоне оз. Байкал, характеризующейся в Западном Прибайкалье сравнительно высокими значениями теплового потока. О достаточно интенсивной гидротермальной деятельности на смежной территории Приольхонья в недавнем прошлом (поздний неоплейстоцен) свидетельствует широкое распространение травертинов и гейзеритов, выходы которых приурочены к северо-восточным разломам [Sklyarov et al., 2004]. Все это отчетливо согласуется с наиболее близким к земной поверхности положением минимума удельного сопротивления, соответствующего Морской межблоковой зоне (см. рис. 2, $)$ ). Перечисленные гидрогеологические особенности являются свидетельством ее высокой тектонической активности по сравнению со структурами аналогичного ранга, но более удаленными от оси Байкальского рифта.

Таким образом, результаты применения различных методов позволяют в первом приближении охарактеризовать подземную гидросферу верхней части земной коры Западного Прибайкалья. Ее состояние определяется тектонической активностью региона, которая в совокупности с изначальной структурно-вещественной спецификой субстрата формирует неоднородное поле нарушенности земной коры, в существенной степени наполненное флюидами. На фоне высокой общей обводненности имеют место аномальные по степени флюидизации зоны, проницаемость которых обусловливается наличием сети разноранговых разрывов и пор, образовавшихся при взаимных перемещениях блоков. В этом плане состояние подземной гидросферы изучаемого региона подтверждает справедливость тех представлений, которые, хотя и были предложены на основе анализа разнотипных (геофизических [Кис- 


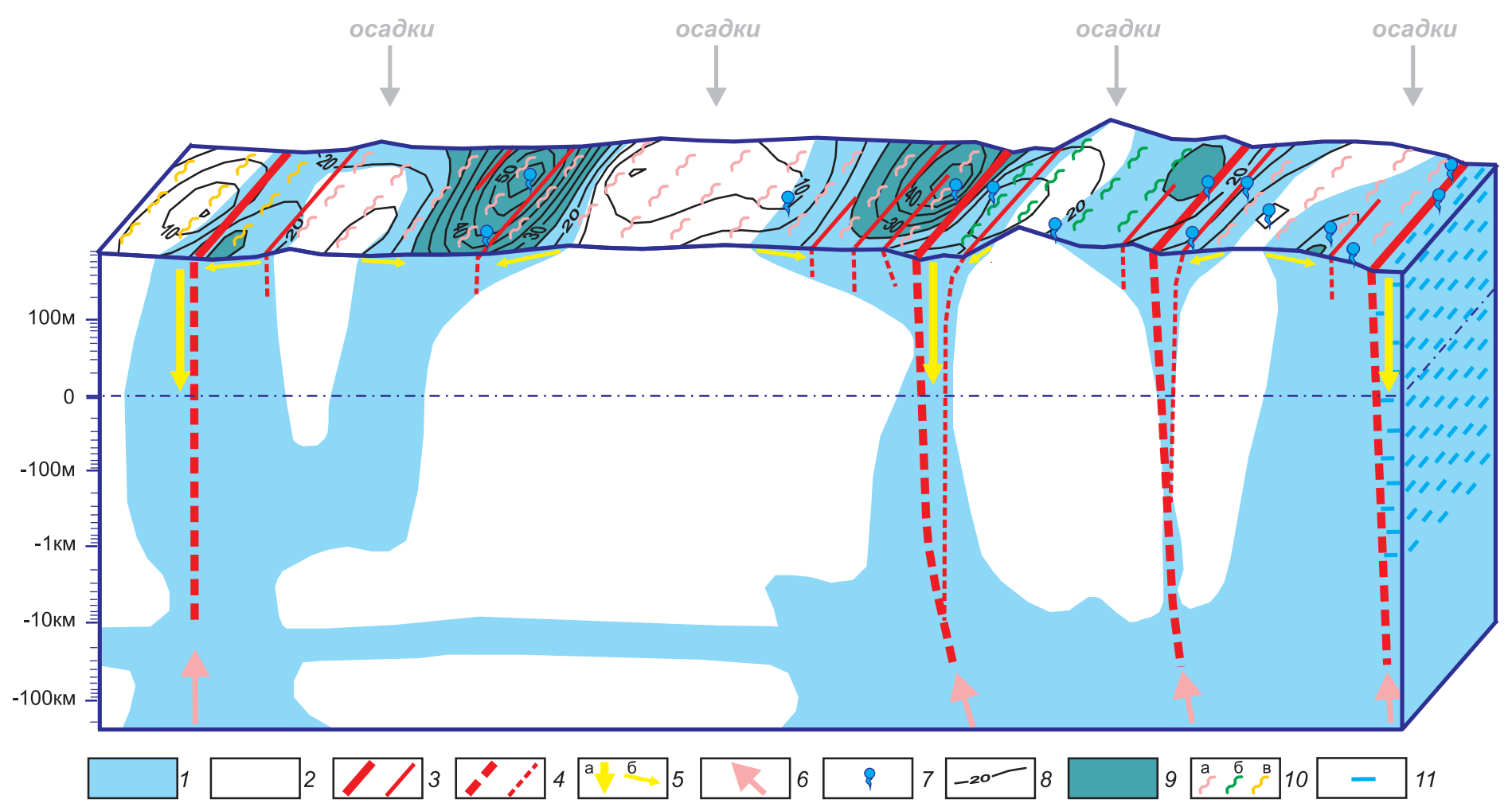

Рис. 8. Концептуальная модель подземной гидросферы западного плеча Байкальского рифта на примере блок-диаграммы участка исследований п. Баяндай - м. Крестовский (Западное Прибайкалье). 1 - флюидопроницаемые межблоковые зоны с аномально низким удельным электрическим сопротивлением (<100 Ом·м), границы которых показаны схематично согласно данным рис. 2, $\Gamma$, и рис. 7; 2 - слабопроницаемые блоки; 3 - крупные и мелкие разломы на земной поверхности; 4 - то же в разрезе (согласно рис. 2, B); 5 - направление миграции метеорных вод: а - субвертикальный нисходящий поток по зонам крупных разломов, б - субгоризонтальный близповерхностный поток от области питания к местам разгрузки; 6 - восходящий флюидный поток по проницаемым зонам; 7 - естественный выход подземных вод (согласно рис. 3); 8 - распределение параметра Н (содержание в пробе воды суммы ионов сульфата и хлора) в изолиниях (согласно рис. 3 , $B$ ); 9 - участки затрудненного водообмена (максимумы параметра Н); 10 - разнотипные приповерхностные воды (согласно рис. 5, 5 ): а кальций-магниевые на участках распространения полихронных метаморфитов Саяно-Байкальского пояса в Приольхонье, а также пород осадочного чехла платформы на Онотской возвышенности и в юго-восточной части Предбайкальского прогиба; б - преимущественно натриево-калиевые на участке распространения гранитоидов приморского комплекса в районе одноименного хребта; в - магниевокальциевые на участке распространения пород осадочного чехла платформы в пределах осевой части Предбайкальского прогиба; 11 - воды оз. Байкал.

Fig. 8. The conceptual model of the underground hydrosphere of the western shoulder of the Baikal rift, as exemplified by the block diagram of the Bayandai - Krestovsky Cape site, Western Pribaikalie. 1 - fluid-permeable inter-block zones with anomalously low specific electrical resistivity $(<100 \mathrm{Om} / \mathrm{m})$, which boundaries are schematically shown according to the data from Fig. $2-\Gamma$ and Fig. $7 ; 2-$ blocks with low permeability; $3-$ large and small faults on the crust surface; 4 - the same in the profile (according to Fig. 2- $B$ ); 5 - direction of meteoric water migration: a - sub-vertical descending flow in zones of large faults, $\sigma$ - sub-horizontal subsurface flow from the feed area towards discharge zones; 6 - ascending fluid flow in permeable zones; 7 - natural discharge of underground water (according to Fig. 3); 8 - distribution of parameters $\mathrm{H}$ (summary contents of sulphate and sodium ions in the water samples) in isolines (according to Fig. $3-B$ ); 9 - sites with impeded water exchange (maximum values of $\mathrm{H}$ ); 10 - subsurface waters of various types (according to Fig. $5-b$ ): a - calcium-magnesium waters on sites with polychrome metamorphic rocks of the SayanBaikal belt in the Priolkhonie, and sedimental rocks of the platform cover at the Onot uplift and the south-eastern part of the Peri-Baikal trough; 6 mainly sodium-calcium waters on the site with granitoids of the Primorsky suite near the Primorsky ridge; в - magnesium-calcium waters on the site with sedimental rocks of the platform cover within the limits of the axial part of the Peri-Baikal trough; 11 - Lake Baikal waters.

син, 1996; Gutmanis et al., 1998; Бердичевский и др., 1996; Neubauer et al., 2005; Becken et al., 2008; и др.] или гидрогеологических [Степанов, 1989; Хаустов, Грабарь, 1999; Бастракова, 1985, 1990; и др.]) данных, но исходили из единой разломно-блоковой модели земной коры.

Главные особенности подземной гидросферы западного плеча Байкальского рифта отражены на рис. 8 в виде блок-диаграммы участка исследований п. Баяндай - м. Крестовский. Основой для построения ее верхней части послужили описанные в статье результаты применения в Западном Прибайкалье комплекса приповерхностных гидрогеологических, структурногеологических и других методов исследования. Нижняя часть составлена по данным глубинных зондирований [Berdichevsky et al., 1999; Семинский и др., 
2010]. Флюидизированные зоны - основной элемент подземной гидросферы - отличаются значительными поперечными размерами у поверхности и на глубине, причем их соотношения со смежными, сравнительно малопроницаемыми блоками, как и многие другие характеристики гидросферы, определяются степенью современной тектонической активности. Так, флюиды, мигрирующие по зонам 3-го порядка в пределах плеча Байкальского рифта, за счет интенсивной деструкции и высоких поровых давлений глубоко проникают в пространства блоков, образуя Обручевскую флюидную систему. Уровни нахождения минимумов удельных сопротивлений в отдельных зонах по мере продвижения к оси рифта уменьшаются (см. рис. 2, Г). Это является косвенным свидетельством приближения к поверхности более высокотемпературных и минерализованных вод, в которых существенную роль играет глубинная составляющая. В то же время размеры флюидизированных зон 3-го порядка достаточно велики на глубинной отметке 10 км (см. рис. 2, $Г$ ) и, таким образом, должны достигать уровня $\approx 12$ км, на котором в результате мелкомасштабных магнитотеллурических зондирований выделена кровля субгоризонтального слоя высокой проводимости [Popov, 1990; Berdichevsky et al., 1999]. Несмотря на существование различных, по-своему аргументированных точек зрения о питании поверхностными [Pinneker et al., 1998] или глубинными [Поспеев, 1998] потоками, этот слой связывает выделенные субвертикальные зоны в единую проницаемую систему, образующую основу подземной гидросферы верхней коры Западного Прибайкалья.

\section{5. Выводы}

В итоге проведения гидрогеологических исследований на участке п. Баяндай - м. Крестовский и совместной интерпретации их результатов с материалами осуществленных ранее геолого-геофизических работ установлены характерные особенности флюидонасыщенности верхней коры западного плеча Байкальского рифта.

1. Подземная гидросфера Западного Прибайкалья на близповерхностном и более глубоких уровнях представляет по большому счету единую систему, строение и состав которой во многом определяются активной зонно-блоковой структурой земной коры.

2. Состояние подземной гидросферы контролируется развитием Байкальского рифта, на западном плече которого, а также в смежном платформенном регионе сформировалась иерархия зон, занимающих в верхней коре субвертикальное положение и являющихся проницаемыми для миграции подземных вод.

3. В пределах тектонически активной части региона, т.е. Обручевской разломной системы, зоны по ширине в среднем превышают поперечные размеры смежных крутозалегающих блоков-пластин, что обу- словливает высокую степень общей обводненности земной коры.

4. Взаимосвязь нарушенности и флюидонасыщенности верхней коры позволяет выявлять специфику зонно-блоковой структуры конкретных регионов, используя гидрогеологическую съемку для самых верхних горизонтов, а «чувствительные» к содержанию флюида геофизические методы (например, МТЗ) - для более глубинных.

5. Интерпретация данных геофизики и гидрогеологии, по крайней мере в тектонически активных регионах, должна исходить из обусловленности изучаемых полей не столько составом пород, сколько структурным состоянием горного массива.

Рассмотренные в статье материалы отражают состояние подземной гидросферы на региональном уровне ее исследования. Детализация установленных закономерностей должна проводиться в укрупненном масштабе, что является темой специального исследования. При этом существование подобия в организации зонно-блоковой структуры на различных иерархических уровнях предопределяет сохранение представленных в статье принципиальных особенностей состояния подземной гидросферы на локальном уровне. В то же время ее структурный каркас будут формировать не только разноранговые разломные зоны, но и коллекторы иного типа, что будет способствовать повышению роли «вещественной составляющей» в формировании подземной гидросферы.

Авторы благодарны сотрудникам ИНГГ СО РАН профессору Н.О. Кожевникову, кандидатам геол.-мин. наук Е.В. Поспеевой и В.В. Оленченко и сотрудникам ИЗК СО РАН кандидатам геол.-мин. наук А.В. Черемных и А.А. Боброву за обсуждение геолого-геофизических материалов, а также ст.-лаборанту А.А. Решиловой - за активное участие в обработке гидрогеологических данных. Работа выполнена в рамках проектов ОНЗ-7.6 и 7.7 (СО РАН) и ФЦП (№ 02.740.11.0446).

\section{6. ЛИТЕРАТУРА}

Аликин Э.Я., Бачин Ю.А. Отчет по геолого-гидрогеологическим и инженерно-геологическим исследованиям, проведенным в районе юго-западного побережья оз. Байкал в 1963-1965 гг. Иркутск, 1965.

Бастракова Н.В. Информативность водно-гелиевой съемки при изучении вопросов формирования подземных вод // Разведка и охрана недр. 1985. № 12. С. 42-46.

Бастракова H.B. Информативность водно-гелиевой съемки при гидрогеологическом изучении платформенных областей // Методы региональных гидрогеологических исследований. М.: ВСЕГИНГЕО, 1990. С. 22-28.

Бердичевский М.Н., Борисова В.П., Голубцова Н.С., Ингеров А.И., Коновалов Ю.Ф., Куликов А.В., Солодилов Л.Н., Чернявский Г.А., Шпак И.П. Опыт интерпретации МТ-зондирований в горах Малого Кавказа // Физика Земли. 1996. № 4. С. 99-117.

Блохин Ю.И. Государственная гидрогеологическая карта СССР, масштаб 1:200000, лист N-48-XXIX (Еланцы) / Ред. В.А. Малий. Иркутск, 1966. 
Блохин Ю.И., Исаченко П.М. Гидрогеологические и инженерногеологические условия листов N-48-XXIX (Еланцы) и N-48$\mathrm{XXX}$ (Гремячинское) (Отчет о гидрогеологических и инженерно-геологических исследованиях 1960-1961 гг.). Иркутск, 1962.

Бондаренко Л.Н. Гидрогеологическая карта СССР. Масштаб 1:200000. Лист N-48-XXXII. Иркутск, 1971.

Борисенко И.М., Бринько М.М., Борисенко Л.В. Гидрогеологические условия Усть-Селенгинской впадины. Лист N-48-XXXV (Кабанск). (Отчет Кабанской партии по гидрогеологической съемке масштаба 1:200000 за 1968-1970 гг.). Улан-Удэ, 1971.

Бурдуковский В.А., Бодрягин В.М., Лавринова Г.Л. Гидрогеологические и инженерно-геологические условия территории листов $\mathrm{N}-48-\mathrm{VI}$ и N-49-1 (Отчет БАМ-Байкальского отряда по работам 1978-1982 гг.). Иркутск, 1982.

Бурдуковский В.А., Еремченко Г.А. Гидрогеологические и инженерно-геологические условия территории листа $\mathrm{N}-48$-XXXIV (Отчет по работам Приморского отряда за 1971-1973 гг.). Иркутск, 1975.

Голубев В.А. Гидротермальный сток и тепловое поле Байкальской рифтовой зоны // Доклады АН СССР. 1988. Т. 302. № 3. С. 575578.

Гуссау Н.А., Исаченко П.М. Промежуточный отчет Тажеранской гидрогеологической съемочной партии по работам 1960 года на территории листов N-48-XXIX и N-48-XXX. Залари, 1961.

Еремченко Г.А., Вьюн Ю.Г. Гидрогеологические и инженерно-геологические условия листа N-48-XXIII (Отчет о гидрогеологической и инженерно-геологической съемках масштаба 1:200000 в 1959-1960 гг.). Залари, 1961.

Замараев C.M. Краевые структуры южной части Сибирской платформы. М.: Наука, 1967. 248 с.

Карта новейшей тектоники юга Восточной Сибири. Масштаб 1:1500000 / Ред. А.Г. Золотарев и П.М. Хренов. М., 1979.

Кауров В.Ф. Гидрогеологическая карта СССР масштаба 1:200000. Серия Ангаро-Ленского артезианского бассейна. Лист N-48XXVIII / Ред. Е.В. Пиннекер. М.: Недра, 1965.

Киссин И.Г. Флюидонасыщенность земной коры, электропроводность, сейсмичность // Физика Земли. 1996. № 4. С. 30-40.

Мац В.Д., Уфимцев Г.Ф., Мандельбаум М.М., Алакшин А.М., Поспеев А.В., Шимараев М.Н., Хлыстов О.М. Кайнозой Байкальской рифтовой впадины: строение и геологическая история. Новосибирск: Изд-во СО РАН, филиал «Гео», 2001. 252 с.

Наумов В.А. Морфология и эволюция краевого шва Сибирской платформы (Северо-Байкальское нагорье). Иркутск: Вост.-Сиб. кн. изд-во, 1974. 143 с.

Нечаева М.В., Распутин В.Ф. Гидрогеологические и инженерногеологические условия территории Баяндаевского листа, масштаб 1:200000. Иркутск, 1961.

Павлов C.X. Гидрогеохимическая зональность на юго-западном фланге Байкальской рифтовой зоны // Тез. докладов Всерос. совещ. по подземным водам востока России. Новосибирск: Изд-во СО РАН, НИЦ ОИГГМ, 2000. С. 50-52.

Перевозников Д.Д. Геоморфология зоны перехода от Байкальского рифта к Сибирской платформе: Автореф. дис. ... канд. географ. наук. Иркутск, 1999. 18 с.

Пиннекер Е.В., Писарский Б.И., Ломоносов И.С., Колдышева Р.Я., Диденко А.А., Шерман С.И. Гидрогеология Прибайкалья. М.: Наука, 1968. 170 с.

Попов А.М. О причинах повышенной электропроводности в земной коре // Геология и геофизика. 1987. № 12. С. 56-65.

Поспеев А.В. Геоэлектрика континентальной тектоносферы: Автореф. дис. ... докт. геол.-мин. наук. Иркутск: Иркутский государственный технический ун-т, 1998. 34 с.

Семинский К.Ж. Тектонофизические закономерности деструкции литосферы на примере Гималайской зоны сжатия // Тихоокеанская геология. 2001. Т. 20. № 6. С. 17-30.

Семинский К.Ж., Гладков А.С., Лунина О.В., Тугарина М.А. Внут- ренняя структура континентальных разломных зон. Прикладной аспект. Новосибирск: Изд-во СО РАН, филиал «Гео», 2005. 293 с.

Семинский К.Ж., Кожевников Н.О., Черемных А.В., Поспеева Е.В., Бобров А.А., Оленченко В.В., Тугарина М.А., Потапов В.В., Бурзунова Ю.П. Межблоковые зоны земной коры: внутренняя структура и геофизические поля // Триггерные эффекты в геосистемах. М.: ГЕОС, 2010. С. 300-308.

Склярова О.А., Скляров Е.В., Федоровский В.С., Санина Н.Б. Минеральные озера Приольхонья: вопросы генезиса и эволюции // География и природные ресурсы. 2004. № 4. С. 44-49.

Скуратовский А.С. Гидрогеологические и инженерно-геологические условия территории листа N-48-XXXIV (Отчет по работам Приморского отряда за 1971-1973 гг.). Иркутск, 1975.

Соотношение древней и кайнозойской структур в Байкальской рифтовой зоне / С.М. Замараев, Е.П. Васильев, А.М. Мазукабзов, В.В. Ружич, Г.В. Рязанов. Новосибирск: Наука, 1979. 126 с.

Степанов В.М. Гидрогеологическая зональность в горных районах Восточной Сибири // Тр. II совещания по подземным водам и инженерной геологии Восточной Сибири. Вып. 1. Иркутск, 1959.

Степанов В.М. Введение в структурную гидрогеологию. М.: Недра, 1989. 229 с.

Уфимцев Г.Ф. Морфотектоника Байкальской рифтовой зоны. Новосибирск: Наука, 1992. 216 с.

Хаустов А.П., Грабарь А.В. Подземные воды блоковых структур и методы их идентификации в кристаллических массивах // Известия вузов. Геология и разведка. 1999. № 3. С. 85-96.

Becken M., Ritter O., Park S.K., Bedrosian P.A., Weckmann U., Weber $M$. A deep crustal fluid channel into the San Andreas Fault system near Parkfield, California // Geophysical Journal International. 2008. V. 173. № 2. P. 718-732. doi:10.1111/j.1365-246X.2008. 03754.x.

Berdichevsky M.N., Vanyan L.L., Koshurnikov A.V. Magnetotelluric sounding in the Baikal rift zone // Izvestiya, Physics of the Solid Earth. 1999. V. 35. № 10. P. 793-814.

Gutmanis J.C., Lanyon G.W., Wynn T.J., Watson C.R. Fluid flow in faults: a study of fault hydrogeology in Triassic sandstone and Ordovician volcaniclastic rocks at Sellafield, North-West England // Proceeding of the Yorkshire Geological Society. 1998. V. 52. №. 2. P. 159-175. doi:10.1144/pygs.52.2.159.

Mats V.D. The structure and development of the Baikal rift depression // Earth-Science Reviews. 1993. V. 34. № 2. P. 81-118. doi:10.1016 /0012-8252(93)90028-6.

Neubauer F., Lips A., Kouzmanov K., Lexa J., Ivăşcanu P. 1: Subduction, slab detachment and mineralization: The Neogene in the Apuseni Mountains and Carpathians // Ore Geology Reviews. 2005. V. 27. № 1-4. P. 13-44. doi:10.1016/j.oregeorev.2005.07.002.

Pinneker E.V., Popov A.M., Shpynev E.B. The depth of surface water penetration into the Earth's Crust: Evidence from the Baikal Region // Doklady Earth Sciences. 1998. V. 359A. № 3. P. 396-399.

Popov A.M. A deep geophysical study in the Baikal region // Pure and applied geophysics. 1990. V. 134. № 4. P. 575-587. doi:10.1007/ BF00878020.

Seminskii K.Zh. Hierarchy in the zone-block lithospheric structure of Central and Eastern Asia // Russian Geology and Geophysics. 2008. V 49. № 10. P. 771-779. doi:10.1016/j.rgg.2007.11.017.

Sklyarov E.V., Fedorovskii V.S., Kulagina N.V., Sklyarova O.A., Skovitina T.M. The Late Quaternary "Geyser Valley" in the Western Flank of the Baikal rift (Ol'khon Region) // Doklady Earth Sciences. 2004. V. 395A. № 3. P. 324-327.

Structural and tectonic correlation across the Central Asia orogenic collage: North-Eastern segment (Guidebook and abstract volume of the Siberian Workshop IGCP-480) / Ed. E.V. Sklyarov. Irkutsk: IEC SB RAS, 2005. 291 p. 

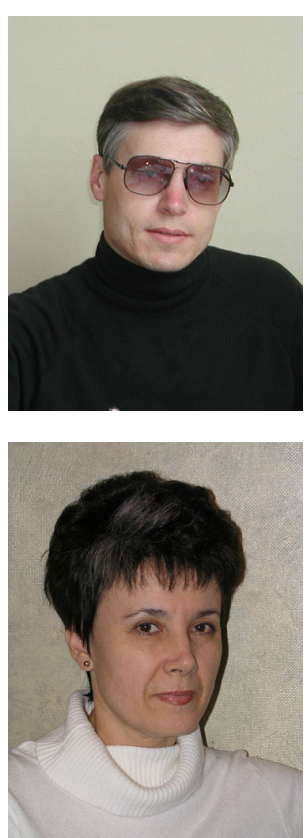

Семинский Константин Жанович, докт. геол.-мин. наук, зав. лабораторией тектонофизики Институт земной коры СО РАН

664033, Иркутск, ул. Лермонтова, 128, Россия

Тел.: 8(3952)423027; $₫$ e-mail: seminsky@crust.irk.ru

Seminsky, Konstantin Zh., Doctor of Geology and Mineralogy, Head of Laboratory of Tectonophysics Institute of the Earth's Crust, Siberian Branch of RAS

664033, Irkutsk, Lermontov street, 128, Russia

Tel.: 8(3952)423027; $\$ e-mail: seminsky@crust.irk.ru

Тугарина Марина Александровна, канд. геол.-мин. наук, доцент

Национальный исследовательский Иркутский государственный технический университет, Институт недропользования, кафедра прикладной геологии

664074, Иркутск, ул. Лермонтова, 83, Россия

Тел.: 8(3952)412686; e-mail: Tmarina@istu.irk.ru

Tugarina, Marina A., Candidate of Geology and Mineralogy, assistant professor Irkutsk State Technical University (National Research University), Institute of Subsoil Use, Applied Geology Chair 664074, Irkutsk, Lermontov street, 83, Russia Tel.: 8(3952)412686; e-mail: Tmarina@istu.irk.ru 